\title{
Nature versus Nurture: The Environment's Persistent Influence through the Modernization of American Agriculture
}

\section{Citation}

Hornbeck, Richard. 2012. Nature versus nurture: The environment's persistent influence through the modernization of American agriculture. American Economic Review 102 (3): 245-249.

\section{Published Version}

doi:10.1257/aer.102.3.245

\section{Permanent link}

http://nrs.harvard.edu/urn-3:HUL.InstRepos:11499011

\section{Terms of Use}

This article was downloaded from Harvard University's DASH repository, and is made available under the terms and conditions applicable to Other Posted Material, as set forth at http:// nrs.harvard.edu/urn-3:HUL.InstRepos:dash.current.terms-of-use\#LAA

\section{Share Your Story}

The Harvard community has made this article openly available.

Please share how this access benefits you. Submit a story.

\section{Accessibility}




\title{
Nature versus Nurture: The Environment's Persistent Influence through the Modernization of American Agriculture
}

\author{
By RICHARD HORNBECK*
}

Environmental challenges are projected to increase through the twenty-first century, and it is natural to consider how new technologies change agricultural dependence on the environment. Technological innovation in agriculture was substantial during the twentieth century. Is there a progression toward "modern" technological control of the environment that replaces a "primitive" dependency on natural advantages and disadvantages? Alternatively, even as new technologies are introduced, is there a persistent dependence of agricultural production on the environment? There often appears to be a wide dispersion of views implicit among economists, environmental historians, scientists, and others on how much technological change mitigates the importance of environmental differences.

The development of the United States' Great Plains offers historical perspective on this fundamental relationship between technology and the environment. During the twentieth century, increased availability of commercial fertilizers compensated for soil nutrient deficiencies. Center pivot irrigation machinery and improved pumps made groundwater from the Ogallala aquifer available in otherwise arid Plains regions (Hornbeck and Keskin 2011). There was substantial mechanical innovation in tractors and harvesters, as well as biological innovation in crop varieties (Olmstead and Rhode 2008) such as hybrid corn (Griliches 1957; Sutch 2011). Some agricultural technologies compensate for environmental disadvantages, and other technologies exploit environmental advantages (Sunding

\footnotetext{
* Harvard University, 232 Littauer Center, Cambridge, MA 02138 and NBER (e-mail: hornbeck@fas.harvard. edu). For helpful comments and suggestions, I thank Ran Abramitzky, Dave Donaldson, Claudia Goldin, Michael Greenstone, Marti Mestieri, Kevin Murphy, Paul Rhode, Wolfram Schlenker, David Zilberman, and seminar participants at NBER and ASSA.

$\dagger$ To view additional materials, visit the article page at http://dx.doi.org/10.1257/aer.102.3.245.
}

and Zilberman 2001); on average, technological innovation may decrease or increase agricultural dependence on the environment.

This paper estimates how the twentieth century modernization of Plains agriculture changed the impact of environmental characteristics on agricultural land values. There is substantial variation among Plains counties in soil type, average precipitation, and average temperature. ${ }^{\top}$ The relative importance of these environmental characteristics for agricultural production are capitalized by differences in agricultural land values, available every five years. From a regression of county land values in each time period on 21 soil type shares, 20 average precipitation bins, or 20 average temperature bins, the dispersion of the estimated coefficients indicates the relative influence of each environmental characteristic.

Despite substantial technological innovation and rising agricultural land values from 1945 to 2002, counties' environmental characteristics largely maintained their influence on land values. Initially more-valuable environmental characteristics remained more valuable; indeed, there was little convergence in the estimated group coefficients for each of the three environmental characteristics. ${ }^{2}$ Most convergence in relative land values occurred before 1945,

\footnotetext{
${ }^{1}$ By limiting the sample to the United States and the Great Plains region, the analysis focuses on areas with similar agricultural technologies, labor and capital markets, goods markets, and institutions. Plains agricultural land values are also relatively unaffected by the small urban land sector.

${ }^{2}$ These results are consistent with the enduring impact of Dust Bowl erosion on Plains counties' land values (Hornbeck forthcoming). Agricultural adaptation mitigated only a small share of the initial losses from erosion, and technological improvements were not biased toward more-eroded areas. Similarly, despite large increases in US crop yields during the twentieth century, crop yields remain persistently sensitive to extreme heat (Schlenker and Roberts 2009, 2011).
} 
consistent with delayed settlement of environmentally disadvantaged areas. ${ }^{3}$

\section{Theory}

The empirical analysis draws on a Ricardianstyle model, in which agricultural land values reflect the production possibility frontier (see, e.g., Mendelsohn, Nordhaus, and Shaw 1994). The value of land in county $c$ and time $t$ is a function of the broadly defined technological frontier $A_{t}$ and a county's environment $E_{c}: V_{c t}\left(A_{t}, E_{c}\right)$. In this stylized model, changes in the technological frontier are unexpected. ${ }^{4}$ County environmental characteristics are distributed among $G$ discrete values.

First, it is useful to consider whether a change in technology preserves environmental advantages or disadvantages.

DEFINITION 1: A change in technology from $A_{1}$ to $A_{2}$ preserves environmental rank of $(i, j) \in G$ if $V_{i 1}\left(A_{1}, E_{i}\right) \geq V_{j 1}\left(A_{1}, E_{j}\right)$ implies that $V_{i 2}\left(A_{2}, E_{i}\right) \geq V_{j 2}\left(A_{2}, E_{j}\right)$.

Second, it is useful to consider how technological change affects the dispersion of environmental advantages or disadvantages.

DEFINITION 2: A change in technology from $A_{1}$ to $A_{2}$ is environment neutral if the standard deviation of land values over environmental characteristics is constant:

$$
\begin{aligned}
& \sqrt{\frac{\sum_{i=1}^{G}\left(V_{i 2}-\overline{V_{2}}\right)^{2}}{G-1}}- \\
& \sqrt{\frac{\sum_{i=1}^{G}\left(V_{i 1}-\overline{V_{1}}\right)^{2}}{G-1}}=0 .
\end{aligned}
$$

By contrast, a change in technology from $A_{1}$ to $A_{2}$ leads to environmental convergence if equation $(1)<0$ and environmental divergence if equation (1) $>0$.

\footnotetext{
${ }^{3}$ American agriculture has expanded substantially into new climates (Olmstead and Rhode 2011).

${ }^{4}$ In practice, some portion of technological change is unexpected and the discount rate is sufficiently high such that land values largely reflect contemporaneous technology.
}

\section{Data Construction}

County-level data are drawn from the US Census of Agriculture (Gutmann 2005; Haines 2005). From 1920 to 2002, every five years, the main variable of interest is the value of agricultural land and buildings per county acre. ${ }^{5}$ The sample is a balanced panel of 967 Plains counties, from 1920 to 2002, with county borders held constant at 1920 definitions (Hornbeck 2010). 6

In the sample region, in aggregate, the fraction of county land settled in farms increased from 0.6 in 1920 to 0.75 in the 1940 s and remained similar through 2002. The nominal value of all agricultural farmland declined moderately from 1920 through 1945, reflecting declining agricultural prices and the Dust Bowl, and increased more than threefold from 1945 through 2002. The real value of agricultural farmland, deflated by a national farm producer price index (NBER), was more constant and increased mainly from 1945 through the 1960s.

County-level environmental characteristics are measured using major soil type, average precipitation, and average temperature. There are 21 major soil groups in the sample region, as defined by the Soil Conservation Service in 1951 (Soil Conservation Service 1951), though some soil groups cover substantially more area than other groups. I County-level average precipitation and average temperature reflect average weather from 1940 to 2000 (PRISM Climate Group 2004). Counties are separated into 20 groups by average precipitation and 20 groups by average temperature.

\section{Empirical Framework}

In the first empirical step, average values by soil group and year are estimated by regressing the $\log$ real value of agricultural land and

\footnotetext{
${ }^{5}$ When data are available separately for land values and building values, the value of land is the largest component of this combined measure. Data are self-reported by farmers, and unsettled land is assumed implicitly to have zero agricultural value.

6 The sample includes counties in Colorado, Iowa, Kansas, Minnesota, Nebraska, New Mexico, North Dakota, Oklahoma, South Dakota, Texas, and Wyoming.

${ }^{7}$ A 1951 SCS map was scanned, traced in GIS software, and merged to 1920 county borders to assign each county the fraction of its area in each soil group (Hornbeck and Keskin 2011).
} 


\section{Panel A. By soil type}

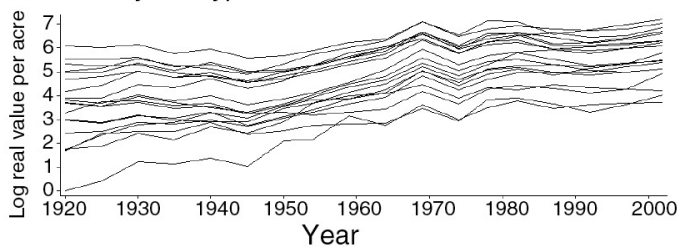

Panel B. By average temperature

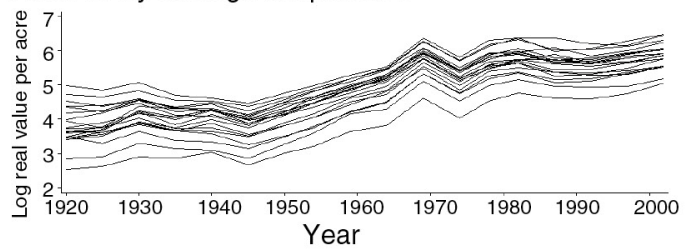

Panel C. By average precipitation

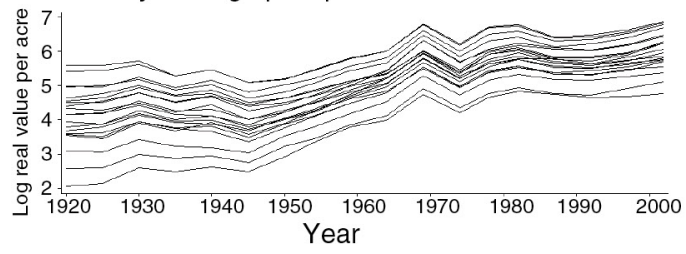

Figure 1. Estimated Mean Land Value, by Environmental Characteristic

Notes: In panel A, each line reflects the average log real value of agricultural land and buildings per county acre for a particular major soil group on the US Plains from 1920 to 2002 (see equation (2) in the text). In panels B and C, each line reflects average land values for counties within a particular range of average temperature and precipitation, respectively.

buildings per county acre on the share of county land in each soil group:

$$
\log V_{c t}=\sum_{i=1}^{G} \theta_{i t} \text { Share }_{c}^{i}+\epsilon_{c t}
$$

For the 20 average precipitation groups and 20 average temperature groups, land values are simply regressed on group-by-year fixed effects. The regressions are weighted by county area, as larger counties represent a larger sample of land values.

In the second empirical step, for each of the three environmental characteristics, the crossgroup standard deviation is estimated in each time period:

$$
\sigma_{t}=\sqrt{\frac{\sum_{i=1}^{G}\left(\theta_{i t}-\bar{\theta}_{t}\right)^{2}}{G-1}} .
$$

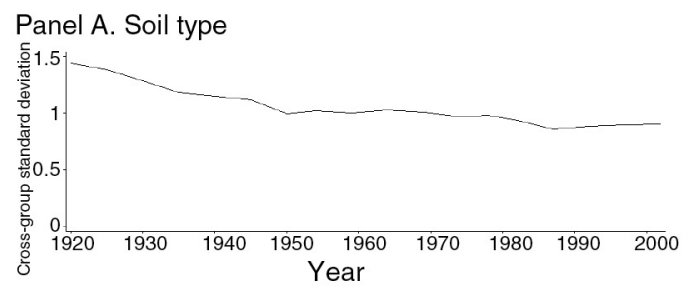

Panel B. Average temperature

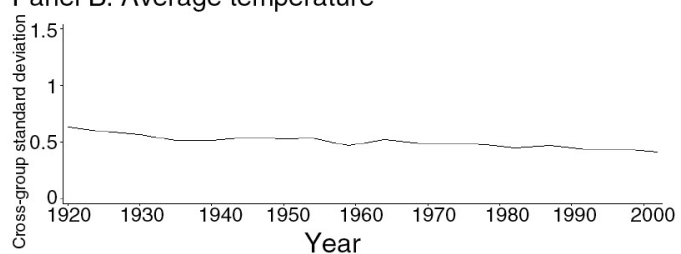

Panel C. Average precipitation

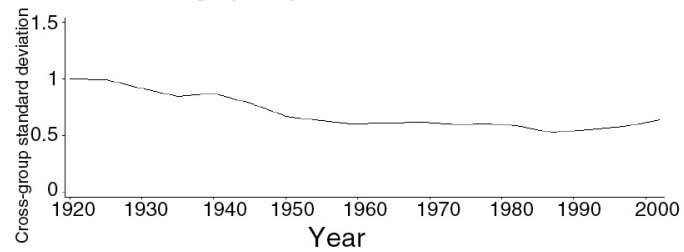

Figure 2. Standard Deviation in Group Land Values, By Environmental Characteristic

Notes: In each time period, from 1920 to 2002, panel A graphs the area-weighted standard deviation in average land values by major soil group (shown in Figure 1A). Panels B and $\mathrm{C}$ graph the area-weighted standard deviation in average land values by average temperature group and average group, respectively.

The standard deviation formula is weighted by group area, as mean land values $\left(\theta_{i t}\right)$ are estimated more precisely for larger groups.

\section{Results}

Figure 1 graphs the estimated coefficients from equation (2) for soil groups ( $\operatorname{panel} \mathrm{A}$ ), average temperature groups (panel $\mathrm{B}$ ), and average precipitation groups (panel C). In each panel, changes over time generally preserve environmental rank; that is, for each pairwise comparison, the more valuable environmental feature generally remains more valuable over time..$^{8}$

\footnotetext{
${ }^{8}$ Moderate temperatures and precipitation levels tend to be more valuable than extreme temperatures and precipitation levels, though it is difficult to display group labels in Figure 1.
} 
Consistent with broad improvements in technology, the low-value environmental features in 2002 is roughly equal to the value of averageor high-value environmental features in 1920. There remains substantial dispersion among the estimated coefficients, however, with little change in dispersion after 1945 as real values increased. ${ }^{9}$

Figure 2 graphs the area-weighted standard deviation over soil groups (panel A), average temperature groups (panel B), and average precipitation groups (panel C). There was some environmental convergence, but mostly before 1945 as the region became increasingly settled. From 1945 through 2002, during most of the increase in real land values, technological change was mainly environment neutral ${ }^{10}$

\section{Conclusion}

Projected changes in the environment will impose greater economic costs if there is less adaptation (Mendelsohn, Nordhaus, and Shaw 1994; Schlenker, Hanemann, and Fisher 2006; Deschenes and Greenstone 2007; Guiteras 2009; Dell, Jones, and Olken 2011). While agricultural technologies may be developed in response to environmental changes, innovation need not be directed toward overcoming environmental disadvantages; indeed, much innovation exploits environmental advantages that may be lost through environmental changes.

On average, during the latter half of the twentieth century, substantial advances in agricultural technology on the United States' Plains have not reduced the importance of natural advantages or disadvantages; instead, environmental characteristics have largely maintained their relative influence on agricultural land values. Even as agricultural technologies have improved substantially, hypothetical changes in these environmental characteristics have not become less costly. Further research may extend this analysis to other regions and time periods, broadening

\footnotetext{
${ }^{9}$ It is difficult to display group precision in Figure 1; in panel A, two rare soil groups that cover less than 0.5 percent of the sample region are omitted for clarity. The two omitted soil groups have low and highly variable estimated land values, with little convergence over time. The estimated standard deviations in Figure 2a include all groups, weighted by group land area.

${ }^{10}$ Changes in the standard deviation are similar when equations (2) and/or (3) are not weighted by land area.
}

our understanding of this fundamental relationship between technology and the environment.

\section{REFERENCES}

Dell, Melissa, Benjamin F. Jones, and Benjamin A. Olken. 2011. "Temperature Shocks and Economic Growth: Evidence from the Last Half Century." Unpublished.

-Deschenes, Olivier, and Michael Greenstone. 2007. "The Economic Impacts of Climate Change: Evidence from Agricultural Output and Random Fluctuations in Weather." American Economic Review 97 (1): 354-85.

-Griliches, Zvi. 1957. "Hybrid Corn: An Exploration in the Economics of Technological Change." Econometrica 25(4): 501-22.

Guiteras, Raymond. 2009. "The Impact of Climate Change on Indian Agriculture.” Unpublished.

Gutmann, Myron P. 2005. "Great Plains Population and Environmental Data: Agricultural Data." ICPSR\# 4254 (last updated April 28, 2005).

Haines, Michael R. 2005. "Historical, Demographic, Economic, and Social Data: The United States, 1790-2000.” ICPSR\# 2896 (last updated June 21, 2005).

Hornbeck, Richard. Forthcoming. "The Enduring Impact of the American Dust Bowl: Short and Long-Run Adjustments to Environmental Catastrophe." American Economic Review.

-Hornbeck, Richard. 2010. "Barbed Wire: Property Rights and Agricultural Development." Quarterly Journal of Economics 125 (2): 767810.

Hornbeck, Richard, and Pinar Keskin. 2011. "The Evolving Impact of the Ogallala Aquifer: Agricultural Adaptation to Groundwater and Climate." National Bureau of Economic Research Working Paper 17625.

Mendelsohn, Robert, William D. Nordhaus, and Daigee Shaw. 1994. "The Impact of Global Warming on Agriculture: A Ricardian Analysis." American Economic Review 84 (4): 75371.

Olmstead, Alan L., and Paul W. Rhode. 2008. Creating Abundance: Biological Innovation and American Agricultural Development. New York: Cambridge University Press.

-Olmstead, Alan L., and Paul W. Rhode. 2011. "Adapting North American Wheat Production to Climatic Challenges, 1839-2009." 
Proceedings of the National Academy of Sciences 108 (2): 480-85.

PRISM Climate Group. "PRISM Climate Group." 2004. http://prism.oregonstate.edu/(accessed July 21, 2011).

-Schlenker, Wolfram, W. Michael Hanemann, and Anthony C. Fisher. 2006. "The Impact of Global Warming on U.S. Agriculture: An Econometric Analysis of Optimal Growing Conditions." Review of Economics and Statistics 88 (1): 113-25.

-Schlenker, Wolfram, and Michael J. Roberts. 2009. "Nonlinear Temperature Effects Indicate Severe Damages to US Crop Yields under Climate Change." Proceedings of the National Academy of Sciences 107 (36): 15594-98.

Schlenker, Wolfram, and Michael J. Roberts. 2011. "The Evolution of Heat Tolerance of Corn: Implications for Climate Change." In The Economics of Climate Change: Adaptations Past and Present, edited by Gary D.
Libecap and Richard H. Steckel, 225-51. Chicago: University of Chicago Press.

Soil Conservation Service. 1951. "Map of Major Soil Groups." National Archives Record Group 114, item 148.

Sunding, David, and David Zilberman. 2001. "The Agricultural Innovation Process: Research and Technology Adoption in a Changing Agricultural Sector." In Handbook of Agricultural Economics, Volume 1A: Agricultural Production, edited by Bruce L. Gardner and Gordon C. Rausser, 20761. Handbooks in Economics, vol. 18. New York: North-Holland.

Sutch, Richard. 2011. "The Impact of the 1936 Corn Belt Drought on American Farmers' Adoption of Hybrid Corn." In The Economics of Climate Change: Adaptations Past and Present, edited by Gary D. Libecap and Richard H. Steckel, 195-223. Chicago: University of Chicago Press. 